Article

\title{
Treatment of Alkaline Stripped Effluent in Aerated Constructed Wetlands: Feasibility Evaluation and Performance Enhancement
}

\author{
Keli He ${ }^{1}$, Tao Lv ${ }^{2}$, Shubiao Wu ${ }^{1, *}$, Luchen Guo ${ }^{1}$, Zeeshan Ajmal ${ }^{1}$, Hongzhen Luo ${ }^{1}$ and \\ Renjie Dong ${ }^{1}$ \\ 1 Key Laboratory of Clean Utilization Technology for Renewable Energy, Ministry of Agriculture, \\ College of Engineering, China Agricultural University, Beijing 100083, China; hekeli@cau.edu.cn (K.H.); \\ guoluchenchen@126.com (L.G.); zisheuaf@gmail.com (Z.A.); luohongzhen@cau.edu.cn (H.L.); \\ rjdong@cau.edu.cn (R.D.) \\ 2 Department of Bioscience, Aarhus University, Aarhus C 8000, Denmark; lvtaocau@gmail.com \\ * Correspondence: wushubiao@gmail.com; Tel.: +86-10-6273-7852
}

Academic Editors: Hans Brix, Carlos A. Arias and Pedro N. Carvalho

Received: 26 July 2016; Accepted: 31 August 2016; Published: 6 September 2016

\begin{abstract}
Ammonium stripping has gained increasing interest for nitrogen recovery in anaerobically digested effluents. However, the stripped effluents often still do not meet discharge standards, having high $\mathrm{pH}$ and residual pollutants. Constructed wetlands (CWs) are an easy to operate ecosystem and have a long history of application in treatment of wastewaters with extreme $\mathrm{pH}$, such as acid mine drainage. However, knowledge of the mechanistic details involved in the use of CWs to treat high alkaline drainage, such as stripped effluent, is insufficient. This study explored the feasibility and effectiveness of using three sub-surface horizontal flow CWs to treat high alkaline stripped effluent $(\mathrm{pH}>10)$. Two intensification strategies-intermittent aeration and effluent recirculation - were evaluated to enhance nitrogen depuration performance. The results show that the treatment of alkaline stripped effluent is feasible due to the high buffering capacity of the wetlands. Effluent recirculation combined with intermittent artificial aeration improves nitrogen removal, with $71 \%$ total nitrogen (TN) removal. Ammonia volatilization from the surface of the wetlands in high alkaline conditions only contributed to $3 \%$ of the total removed ammonium. The microbial abundance and activity had significant diversity for the various enhancement strategies used in the constructed wetland systems. Anammox is an important process for nitrogen removal in CWs treating alkaline stripped effluent, and possible enhancements of this process should be investigated further.
\end{abstract}

Keywords: horizontal flow constructed wetlands; stripped effluent; high alkalinity drainage; nitrogen removal

\section{Introduction}

Currently, there are many concerns about how to dispose of the large amounts of waste generated by pig farms. Swine wastewater is a typical high strength wastewater containing high levels of organic matter, ammonia, and phosphorus [1]. Inappropriate treatment methods and indiscriminate discharge of swine wastewater could cause epidemic diseases and foul odours. Anaerobic digestion (AD) is considered an effective and economic technique for treating swine wastewater. It has the advantages of both energy recycling and reduced greenhouse gas emissions [2]. Nevertheless, large amounts of liquid digestate are often generated, particularly from large- and super-large-scale biogas plants. Because the digestate contains $>97 \%$ water, transport costs for lorries and underground pipelines prevent transportation to farmlands large distances away from the biogas plant [3]. Furthermore, upon excess application of digestate in the limited farmland near anaerobic digesters, the demand 
often exceeds the land's capacity, which consequently causes environmental problems [4]. Therefore, large- and super-large-scale AD without recovery or removal of the nutrients from the digestate in areas with limited arable land nearby is not a viable option [5].

Various methods have been explored for recovering nutrients from digestate, including struvite formation [6], ammonia stripping [7], biological membrane reactors [8], and ion exchange resins [9]. Of these methods, ammonia stripping is considered one of the best [10], due to its moderate reagent and facility operation. Lime was commonly chosen as the external alkaline addition to improve the $\mathrm{pH}$ in the ammonia stripping technology, thus, phosphorous can be thoroughly removed through flocculation. However, residual nutrient contents, such as COD (1000 mg/L) and TN $(250 \mathrm{mg} / \mathrm{L})$, in the stripped effluents are still not comply with wastewater discharge standards. Particularly, the stripped effluents are often characterized by high $\mathrm{pH}$ values, which would significantly increase the difficulty and cost of post-treatment by traditional biological processes.

Constructed wetlands (CWs) are artificial systems that employ natural processes, including aquatic plants, substrates, and associated microorganism communities in a synergistic manner to treat wastewater [11]. CWs are a well-established eco-treatment technology used for a diverse range of wastewaters such as industrial wastewater [12,13], landfill leachate [14], and agricultural wastewater [15], and have long been used to treat acid mine drainage [16]. However, the potential of CWs to treat alkaline drainage (HAD) is not well understood [17]. The HAD could cause toxic effects for denitrifying and nitrifying bacteria. Moreover, knowledge of pollutant removal mechanisms and transformation pathways in a very alkaline environment is insufficient.

The aim of this study was to explore the feasibility and effectiveness of using horizontal sub-surface flow constructed wetlands (HSFCWs) to treat highly alkaline effluent from ammonium stripping. Two enhancement strategies-intermittent aeration and effluent recirculation-were evaluated to enhance the nitrogen depuration efficiency. The response of the microbial community to alkaline wastewater and the two enhancement strategies has been assessed by a quantification of ammonia-oxidizing bacterial (AOB), ammonia-oxidizing archaeal (AOA), nitrite reductases (nirS and nirK), and Anammox in wetland beds.

\section{Materials and Methods}

\subsection{Laboratory-Scale Wetlands}

Three pilot-scale horizontal sub-surface flow constructed wetlands (HSFCWs) were constructed in Plexiglass rectangular tanks: CW-1, CW-2, and CW-3 (100 cm in length; $15 \mathrm{~cm}$ in width; $50 \mathrm{~cm}$ in depth). The schematic diagram of the systems are shown in Figure 1. The tanks were filled with $100 \mathrm{~kg}$ of gravel (diameter, $2 \mathrm{~mm}$ to $6 \mathrm{~mm}$; density, $1.67 \mathrm{~g} / \mathrm{cm}^{3}$; porosity, $35 \%$ ) to a height of $45 \mathrm{~cm}$. The water level was maintained at approximately $5 \mathrm{~cm}$ below the gravel bed surface. Sieves of perforated plastic were placed $3 \mathrm{~cm}$ in front of both the inlet and the outlet of the gravel bed to create small inflow and outflow zones. The free liquid volume was specially designed to ensure an equal distribution of inflow and laminar (plug) liquid flow through the gravel bed.

Black plastic cloth was wrapped around the sidewalls of the HSFCW to prevent periphyton formation. Juncus effusus, a species native to Asia and other parts of the world, was planted in the three HSFCWs at a density of 70-80 stalks per wetland. The experimental installation was situated in the Bioenergy and Environmental Science \& Technology Laboratory at the China Agricultural University. Operational conditions were chosen to simulate an average summer day in moderate climatic conditions. The temperature was set at $22{ }^{\circ} \mathrm{C}$ from 6 A.M. to 9 P.M. and $16{ }^{\circ} \mathrm{C}$ from 9 P.M. to 6 A.M. to simulate daytime and night-time conditions, respectively. Lamps (Master SON-PIA $400 \mathrm{~W}$; Phillips, Shanghai, China) were switched on during the day as an additional artificial light source when natural illumination was below $60 \mathrm{klx}$. 


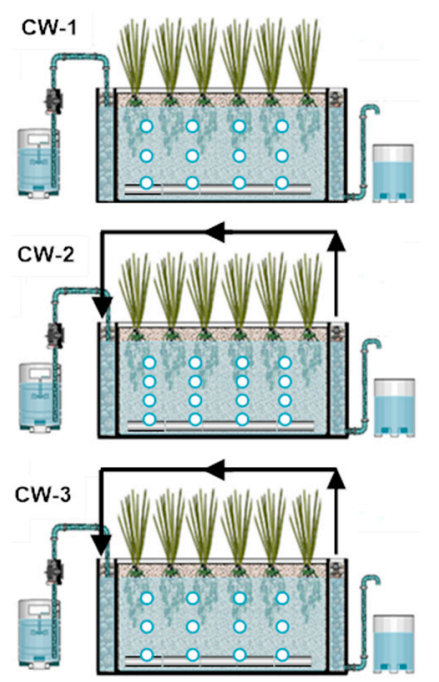

Figure 1. Schematic diagram of the three pilot-scale horizontal subsurface-flow constructed wetlands.

\subsection{Experimental Conditions}

This study investigated the feasibility of using HSFCWs for post-treatment of anaerobically digested alkaline supernatant after an ammonium stripping process. The experiment was conducted by varying the specific operational conditions of aeration frequency and recirculation ratio. An air bar connected to an air pump intermittently supplied air to the bottom of the HSFCWs with a flow rate of about $180 \mathrm{~L} / \mathrm{h}$ to introduce aeration. The hydraulic loading rate was maintained at $33.3 \mathrm{~L} / \mathrm{m}^{2} \cdot \mathrm{d}$ during the entire experiment. CW-1 was aerated for $1 \mathrm{~h}$ on, $5 \mathrm{~h}$ off without effluent recirculation; CW-2 was aerated for $1 \mathrm{~h}$ on, $1 \mathrm{~h}$ off with effluent recirculation at a ratio of 1:1; and CW-3 was aerated for $1 \mathrm{~h}$ on, $5 \mathrm{~h}$ off with an effluent recirculation ratio of 1:1.

The original anaerobic digestate supernatant used in this study was collected from a mesophilic biogas plant located in the Dong Hua Shan Village, Shunyi District, Beijing, China (40 06'24.59" N, $\left.116^{\circ} 54^{\prime} 30.68^{\prime \prime} \mathrm{E}\right)$. The influent for the three HSFCWs was collected from the effluent of a $14 \mathrm{~h}$ ammonia stripping process every month. The $\mathrm{pH}$ of the influent was in a range of 9.7-10.5. Detailed compositions of the anaerobically digested liquid fraction following air stripping (influent of HSFCWs) are provided in Table 1.

Table 1. Influent compositions of the three horizontal sub-surface flow constructed wetlands.

\begin{tabular}{cc}
\hline Parameters & Influent \\
\hline $\mathrm{pH}$ & $10.0 \pm 0.5$ \\
$\mathrm{DO}$ & $0.01 \pm 0.01$ \\
Temperature $\left({ }^{\circ} \mathrm{C}\right)$ & $18 \pm 2$ \\
$\mathrm{COD}(\mathrm{mg} / \mathrm{L})$ & $1311 \pm 60$ \\
$\mathrm{NH}_{4}{ }^{-}-\mathrm{N}(\mathrm{mg} / \mathrm{L})$ & $264 \pm 25$ \\
$\mathrm{NO}_{2}{ }^{-}-\mathrm{N}(\mathrm{mg} / \mathrm{L})$ & $1.2 \pm 0.2$ \\
$\mathrm{NO}_{3}{ }^{-}-\mathrm{N}(\mathrm{mg} / \mathrm{L})$ & $0.7 \pm 0.4$ \\
$\mathrm{TN}(\mathrm{mg} / \mathrm{L})$ & $266 \pm 30$ \\
Alkalinity $(\mathrm{mg} / \mathrm{L})$ & $2968 \pm 215$ \\
\hline
\end{tabular}

\subsection{Sampling and Analysis}

The experiment was conducted from November 2015 to March 2016, approximately 110 day. The influent and effluent samples were collected three times per week. For each sample, the $\mathrm{pH}$ value and dissolved oxygen (DO) were immediately measured in situ using a portable Orion 5-Star multimeter with a pH electrode (LE438; Mettler-Toledo Instruments (Shanghai) Co., Ltd. Shanghai, 
China) and DO electrode (SN404735; Mettler-Toledo Instruments (Shanghai) Co., Ltd. Shanghai, China). Nitrate-nitrogen was analysed by continuous flow colorimetry (SEAL AutoAnalyzer 3; SEAL Analytical GmbH., Hordersted, Germany). After pre-treatment and reagent addition following standard methods (AWWA and WEF, 1998), concentrations of ammonium ( $\mathrm{NH} 4^{+}-\mathrm{N}$; phenate method 4500-NH3 F) and nitrite $\left(\mathrm{NO}_{2}{ }^{-}-\mathrm{N} ; 4500-\mathrm{NO}_{2}{ }^{-}\right.$B; colorimetric method) were measured using a UV-Vis spectrophotometer (Gold S54T; Lengguang Tech, Shanghai, China). Chemical oxygen demand (COD) was measured using a Hach DR5000 spectrophotometer that was calibrated and operated according to manufacturer instructions (Method 8000).

The venting method was used to measure ammonia gas volatilization from the three constructed wetlands, which used a traditional enclosure with sponge-trapping and $\mathrm{KCl}$ extraction methods [18]. The ammonia volatilization samples were collected every month in three replicates (four sampling campaigns) for each HSFCW during the whole experiment.

\subsection{Quantification of $A O A, A O B$, nirs, nirK, and Anammox}

The copy numbers of AOA and AOB, nirS, nirK, and Anammox were quantified with a real-time PCR system (ABI7500, Applied Biosystems, California, CA, USA) and SYBR green qPCR mix (Takara, Japan). The primer sequences, target gene lengths, and annealing temperatures are shown in Table 2. The thermal cycling parameters were as follows: $10 \mathrm{~min}$ at $95^{\circ} \mathrm{C}, 40$ cycles of $15 \mathrm{~s}$ at $94{ }^{\circ} \mathrm{C}, 20 \mathrm{~s}$ for annealing at the temperature given in Table 2 , and $40 \mathrm{~s}$ at $72{ }^{\circ} \mathrm{C}$. All PCR reactions were performed in triplicate, and product specificity was tested through gel electrophoresis and melting curve analysis. The copy number in the samples was calculated based on external standard curves. The correlation coefficients $\left(\mathrm{R}^{2}\right)$ for standard curves were larger than 0.99 . The values were expressed as gene copies per gram substrate.

Table 2. Primer sequences and annealing temperature.

\begin{tabular}{|c|c|c|c|c|c|}
\hline $\begin{array}{l}\text { Name of } \\
\text { Primers }\end{array}$ & $\begin{array}{l}\text { Bacterial } \\
\text { Group }\end{array}$ & Sequence & $\begin{array}{l}\text { Amplified } \\
\text { Length (bp) }\end{array}$ & $\begin{array}{c}\text { Annealing } \\
\text { Temperature }\left({ }^{\circ} \mathrm{C}\right)\end{array}$ & Ref. \\
\hline nirK & \multirow{2}{*}{$\begin{array}{l}\text { Denitrifying } \\
\text { bacterial }\end{array}$} & $\begin{array}{c}\text { FlaCu: } \text { 5'-ATCATGGT(C/G)CTGCCGCG-3' }^{\prime} \\
\text { R3Cu: 5'-GCCTCGATCAG(A/G)TTGTGGTT-3' }\end{array}$ & 472 & 60 & [19] \\
\hline nirS & & $\begin{array}{l}\text { cd3aF: 5'-GT(C/G)AACGT(C/G)AAGGA(A/G)AC(C/G)GG-3' } \\
\text { R3cd: 5'-GA(C/G)TTCGG(A/G)TG(C/G)GTCTTGA-3' }\end{array}$ & 425 & 58 & [19] \\
\hline $\mathrm{AOB}$ & $\begin{array}{l}\text { Nitrifying } \\
\text { bacterial }\end{array}$ & $\begin{array}{c}\text { amoA-1F: 5'-GGGGTTTCTACTGGTGGT-3' } \\
\text { amoA-2R: 5'-CCCCTCKGSAAAGCCTTCTTC-3' }\end{array}$ & 491 & 55 & [20] \\
\hline $\mathrm{AOA}$ & Archaea & $\begin{array}{l}\text { Arch-amoAF: 5'-STAATGGTCTGGCTTAGACG-3' } \\
\text { Arch-amoAR: 5'-GCGGCCATCCATCTGTATGT-3' }\end{array}$ & 635 & 53 & [20] \\
\hline Anammox & $\begin{array}{l}\text { Anammox } \\
\text { bacterial }\end{array}$ & $\begin{array}{c}\text { AMX809F:5'-GCCGTAAACGATGGGCACT-3' } \\
\text { AMX1066R:5'-AACGTCTCACGACACGAGCTG-3' }\end{array}$ & 258 & 60 & [21] \\
\hline $\begin{array}{l}16 \mathrm{~S} r \\
\text { RNA }\end{array}$ & / & $\begin{array}{l}\text { 1369-F: 5'-CGGTGAATACGTTCYCGG-3' } \\
\text { 1541-R:5'-AAGGAGGTGATCCRGCCGCA-3' }\end{array}$ & 172 & 53 & [22] \\
\hline
\end{tabular}

\subsection{Calculations}

The alkalinity reduction attributed to microbial nitrogen transformations was calculated based on the following equation [23]:

$$
\Delta \mathrm{Alk}_{\text {theory }}(\mathrm{mg} / \mathrm{L})=\delta\left([\mathrm{TN}]_{\text {inf. }}-[\mathrm{TN}]_{\text {eff. }}\right)+7.14\left[\mathrm{NO}_{3}{ }^{-}\right]_{\text {eff. }}
$$

where $[\mathrm{TN}]_{\text {inf. }}$ and $[\mathrm{TN}]_{\text {eff. }}$ are the total nitrogen concentration of influent and effluent $(\mathrm{mg} / \mathrm{L})$, Theoretically, the difference between influent and effluent alkalinity was $\delta=7.14-3.57=3.57$ $\left(\mathrm{mg} / \mathrm{L} / \mathrm{mg} / \mathrm{L} \mathrm{N}\right.$ removed). $\left[\mathrm{NO}_{3}{ }^{-}\right]_{\text {eff. }}$ is the $\mathrm{NO}_{3}{ }^{-}-\mathrm{N}$ concentration in the effluent $(\mathrm{mg} / \mathrm{L})$. 


\subsection{Statistical Analysis}

Statistical analysis was carried out using SPSS 20.0 for Windows. The data were subjected to one-way ANOVA to test for statistical significance. Homogeneity of the variances was assessed using the Levene test prior to ANOVA. For multiple comparisons between mean values, Tukey's HSD test was applied with a significance level of $p=0.05$.

\section{Results}

\subsection{Physicochemical Parameters}

The DO in the effluent of CW-1 (average of $0.31 \mathrm{mg} / \mathrm{L}$ ) was significantly lower than that in CW-2 and CW-3, where DO were $1.63 \mathrm{mg} / \mathrm{L}$ and $1.25 \mathrm{mg} / \mathrm{L}$, respectively (Figure 2). The differences between the three experimental wetlands not only indicate an improvement in oxygen condition with increased aeration, but also show that effluent recirculation may bring a considerable amount of oxygen into the wastewater. Similar results were also found by Sun et al. [24].

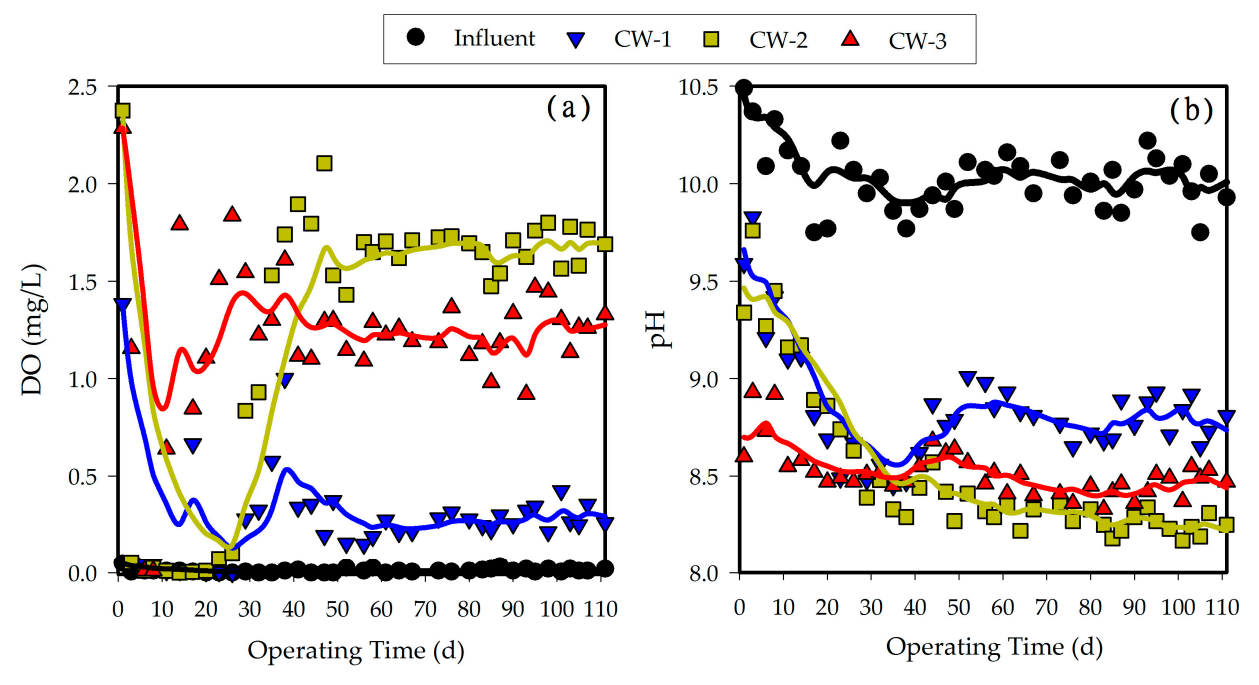

Figure 2. Dynamics of the concentration of DO and $\mathrm{pH}$ in influent and effluent. (a) DO; (b) pH.

Both influent and effluent $\mathrm{pH}$ values were higher than 8 in this study (Figure 2). Wastewater $\mathrm{pH}$ is a vital factor that affects nitrification, denitrification, and anaerobic organic degradation in constructed wetlands. Nitrification and denitrification processes can be decreased to a negligible level at $\mathrm{pH}>8.0$ [25]. Thus, the influent $\mathrm{pH}$ value of 10 was much higher than the proper $\mathrm{pH}$ condition for normal microbial activity. Moreover, previous studies have shown that high $\mathrm{pH}$ can cause a reduction of DO levels in substrate [26], thus affecting nitrification and denitrification processes.

During the entire experiment, the effluent $\mathrm{pH}$ of $\mathrm{CW}-2$ was the lowest which may due to the higher aeration regime (1:1). The higher nitrification process could happen under relative aerobic condition and produce hydrogen ion to neutralization the hydroxyl ion. Additionally, the main mechanism responsible for buffering alkaline wastewater in treatment wetlands is caused by high partial pressure of carbon dioxide $\left(\mathrm{pCO}_{2}\right)$. The high pressure can arise from both active aerobic and anaerobic microbial respiration. The produced carbon dioxide not only decreases $\mathrm{pH}$, but also accelerates calcium carbonate $\left(\mathrm{CaCO}_{3}\right)$ precipitation rates and consumes alkalinity $[27,28]$. Therefore, the lower $\mathrm{pH}$ in $\mathrm{CW}-2$ compare with $\mathrm{CW}-3$ may be due to a longer aeration time enhancing the microbial organic carbon transformations and producing a high partial pressure of carbon dioxide. When compare with the effluent $\mathrm{pH}$ in $\mathrm{CW}-1$, the lower $\mathrm{pH}$ in $\mathrm{CW}-2$ may be due to the effluent recirculation at a ratio of $1: 1$, which diluted the influent wastewater. 


\subsection{COD and Alkalinity Removal Performance}

In the present study, the effluent COD concentration varied from 687 to $858 \mathrm{mg} / \mathrm{L}$ with an average removal efficiency of $40 \%$, and the three HSFCWs did not show significant difference (Figure 3). In our study recirculation did not have an effect on COD removal, even though previous studies have found the effluent recirculation enable a $15 \%$ enhancement in pollutant removal performance attributed to the increase in contact time $[29,30]$.

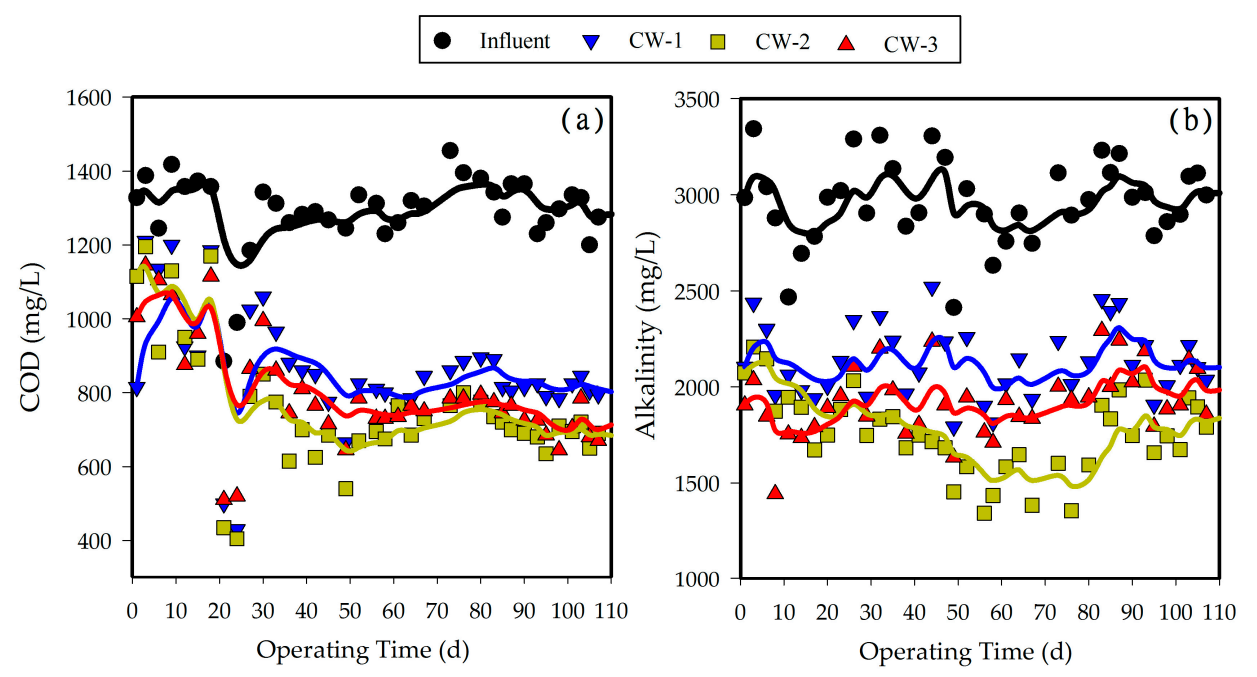

Figure 3. Dynamics of the concentration of COD and alkalinity in influent and effluent. (a) COD; and (b) alkalinity.

In this study, the average influent concentration of alkalinity was around $3000 \mathrm{mg} / \mathrm{L}$ (Table 1). After wastewater passed though the experimental wetlands, the reductions of alkalinity were 810, 1204 , and $1041 \mathrm{mg} / \mathrm{L}$, with average removal efficiencies of $28 \%, 42 \%$, and $35 \%$ in CW-1, CW-2, and CW-3, respectively (Figure 3). Alkalinity is a good indicator for the buffering capacity of treatment wetland systems when treating extreme $\mathrm{pH}$ wastewaters. Usually, alkalinity in wastewater must be higher than $80-100 \mathrm{mg} / \mathrm{L}$ to maintain adequate buffer capacity [31].

The dynamics of alkalinity can be influenced by both microbial carbon and nitrogen transformations, thus the determination of contributions from each process is very important. Alkalinity of the wastewater can be consumed at rate of $7.14 \mathrm{~g} / \mathrm{g}$ Nitrogen oxidized during nitrification and generated at rate of $3.57 \mathrm{~g} / \mathrm{g}$ Nitrogen reduced during denitrification [23]. After the influent passes through the wetland bed with simultaneous nitrification and denitrification processes, the effluent alkalinity is often lower than the influent alkalinity. The difference between influent and effluent alkalinity can be defined theoretically as $\delta=7.14-3.57=3.57 \mathrm{mg} / \mathrm{L} / \mathrm{mg} / \mathrm{L} \mathrm{N}$ removed. Therefore, the alkalinity reduction attributed to microbial nitrogen transformations was calculated to be $505 \mathrm{mg} / \mathrm{L}$ in CW-1, $980 \mathrm{mg} / \mathrm{L}$ in CW-2, and $849 \mathrm{mg} / \mathrm{L}$ in CW-3 based on the Equation (1). Considering an alkalinity reduction of $810 \mathrm{mg} / \mathrm{L}$ in CW-1, $1203 \mathrm{mg} / \mathrm{L}$ in CW-2, and $1040 \mathrm{mg} / \mathrm{L}$ in CW-3 (Figure 3), the contribution of a buffering effect from microbial nitrogen transformations was about $62 \%, 81 \%$, and $83 \%$, respectively. This demonstrates that recirculation would be an important enhancement strategy to improve the buffering capacity when treating extreme $\mathrm{pH}$ wastewaters.

\subsection{Nitrogen Removal Performance}

The effluent ammonium nitrogen in CW-1 (without recirculation and $1 \mathrm{~h}$ on $/ 5 \mathrm{~h}$ off intermittent aeration) was about $126 \mathrm{mg} / \mathrm{L}$ (removal efficiency of 52\%), which was much higher than that in CW-2 and CW-3. The average effluent concentrations were $25 \mathrm{mg} / \mathrm{L}$ and $47 \mathrm{mg} / \mathrm{L}$ with removal efficiencies of $90 \%$ and $82 \%$ in CW-2 and CW-3, respectively (Figure 4). Ammonium nitrogen, at 
a mean concentration of $264 \mathrm{mg} / \mathrm{L}$ in the influent, constituted $99 \%$ of the TN, while nitrate nitrogen, nitrite nitrogen, and organic nitrogen constituted less than $1 \%$ of the TN. Improved oxygen conditions in CW-2 and CW-3, created by a longer aeration time and effluent recirculation, were the main factors increasing the ammonium removal.

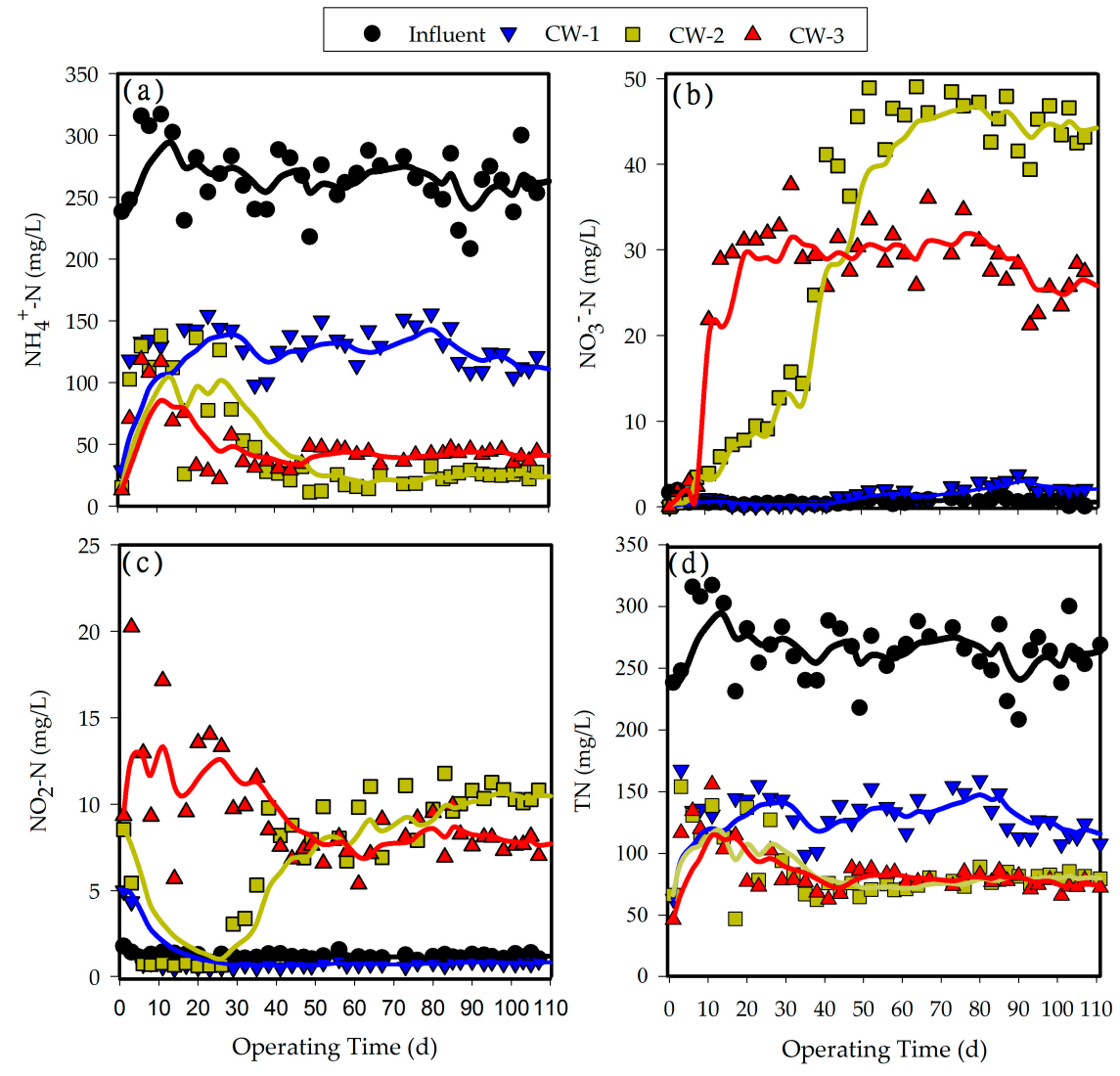

Figure 4. Dynamics of the concentration of nitrogen species in influent and effluent. (a) ammonia nitrogen; (b) nitrate nitrogen; (c) nitrite nitrogen; (d) total nitrogen (TN).

The ammonia gas volatilization rate in CW-2 was an average of $13.8 \mathrm{mg} / \mathrm{m}^{2} \cdot \mathrm{d}$, which was significantly higher than in CW-1 and CW-3, where rates were 11.8 and $12.6 \mathrm{mg} / \mathrm{m}^{2} \cdot \mathrm{d}$, respectively (Figure 5). Ammonia nitrogen can be removed through various mechanisms in CWs, e.g., nitrification, denitrification, anammox, and ammonia volatilization. It is well established that at $\mathrm{pH}>9.3$, the ratio between ammonia and ammonium ions is $1: 1$, and nitrogen losses via volatilization are significant [32]. Considering the highly alkaline influent wastewater with $\mathrm{pH}>10$ in this study, the venting method was used to measure ammonia gas volatilization rates from the three CWs. The primary cause of these differences was the higher aeration frequency, which promotes the disturbance of bubbles carrying ammonia and increases the ammonia volatilization rate. Although the study measured high ammonia volatilization rate, according to nitrogen mass balance calculations, the total volatilized $\mathrm{NH}_{3}$ from our experimental constructed wetlands accounted for a mere $3.0 \%, 3.5 \%$, and $3.2 \%$ of the total removed ammonium nitrogen. The results demonstrated ammonia volatilization is not the primary mechanism removing ammonia nitrogen in the present study, which indicated the potentially important role of the biological transformations on nitrogen depuration. 


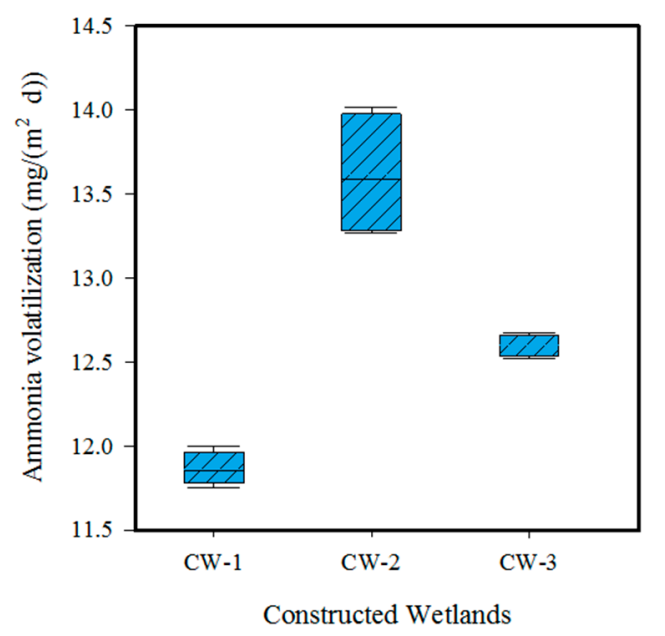

Figure 5. Ammonia volatilization rates of horizontal subsurface-flow constructed wetlands with an HRT of 5 days.

In the classic nitrogen removal routes, ammonia-oxidizing bacteria (AOB) first oxidize ammonia nitrogen to nitrite nitrogen, after which nitrite-oxidizing bacteria (NOB) oxidize nitrite nitrogen to nitrate nitrogen in aerobic conditions. Because wetlands contain a system of complex aerobic, anoxic, and anaerobic zones within the same units, which provide a perfect habitat for the coexistence of different microbial communities. Accumulated $\mathrm{NO}_{3}{ }^{-}-\mathrm{N}$ from the nitrification process must be processed via anaerobic microbial denitrification in order to be permanently removed from the wastewater [33]. Many factors, such as biodegradable organic carbon sources, dissolved oxygen concentrations, and $\mathrm{pH}$ could restrict the completion [34]. A longer aeration time and effluent recirculation brought a considerable amount of oxygen into the constructed wetlands, increasing the ammonia removal rate. However, as shown in Figure 4, in CW-2 and CW-3 (with enhanced intermittent aeration and recirculation), nitrate accumulated to 44 and $28 \mathrm{mg} / \mathrm{L}$, respectively.

Factors, such as an anaerobic environment and availability of a biodegradable organic carbon source, could restrict the denitrification process. Because the influent in this study was alkaline anaerobic digested slurry after ammonium stripping, during which the easily degradable portion of organic matter had already transformed into methane $\left(\mathrm{CH}_{4}\right)$ and carbon dioxide $\left(\mathrm{CO}_{2}\right)$ through anaerobic digestion process [35]. This may cause the limited COD removal efficiency (average of $40 \%$ ). Accordingly, an organic carbon source with easy biodegradation for the denitrification process would be also limited. Therefore, the higher TN removal performance in CW-2 (71\%) and CW-3 (69\%) as compared to CW-1 (52\%, Figure 4) demonstrated the benefit of recirculating nitrate-rich effluent back to the wetland inflow region, which can utilize the available organic matter for denitrification and result improving TN removal.

In a CW system, microorganism community plays a significant role in the nitrogen transfer process. The metabolism of the microorganism contributed $60 \%-90 \%$ of TN removal using HSFCWs [36]. The study used different DO control strategies (artificial aeration ratio of $1 \mathrm{~h}$ on/1 h off and $1 \mathrm{~h}$ on $/ 5 \mathrm{~h}$ off) and effluent recirculation (with or without recirculation) to illustrate the microbial abundance and activity in different wetland systems. As shown in Figure 6, the number of copies of ammonium oxidizing genes (AOB and $\mathrm{AOA}$ ) in $\mathrm{CW}-1$ was relatively lower than in CW-2 and CW-3. This illustrates the positive function of effluent recirculation and intermittent aeration on the nitrification process. The abundances of nirK and nirS genes are often used as nitrite reduction markers to study the denitrifying bacterial community [37]. The number of copies of both nirK and nirS were significantly higher in CW-1 and CW-3 compare with CW-2. The reason may be the lower aeration regimes in $\mathrm{CW}-1$ and $\mathrm{CW}-3$ could cause the relative anaerobic condition, which is more suitable for denitrification. 

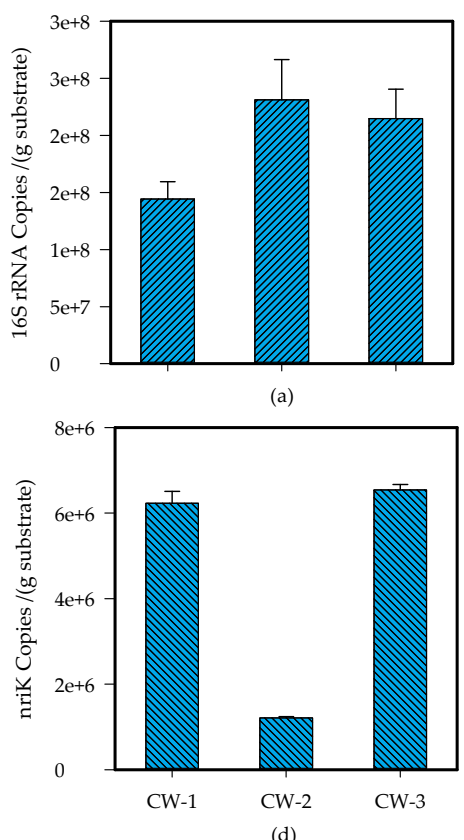

(d)

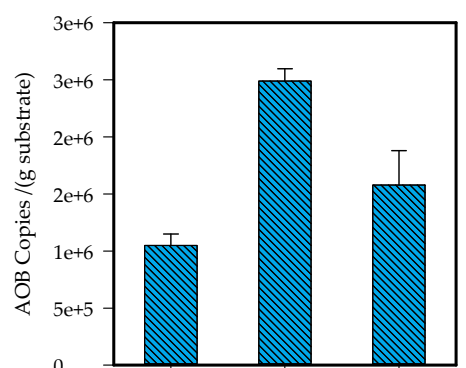

(b)

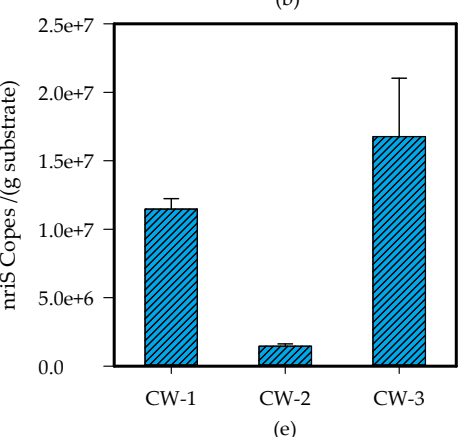

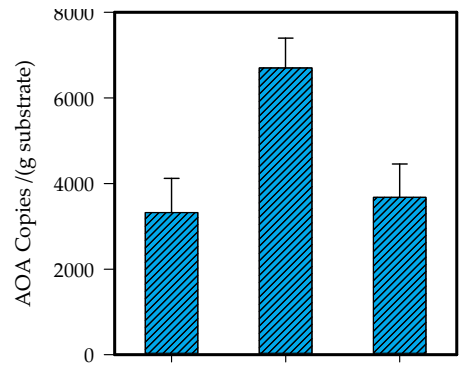

(c)

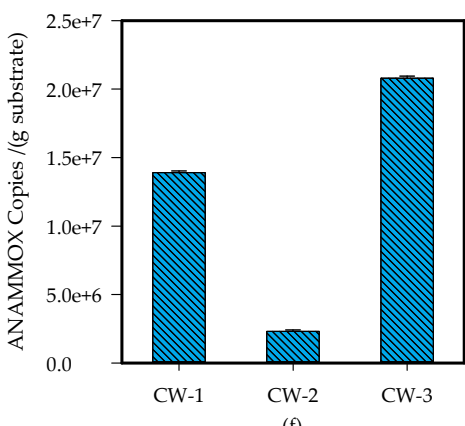

(f)

Figure 6. Gene copy number of $16 \mathrm{~S}$ rRNA, AOB, AOA, nriK, nriS, Anammox. (a) $16 \mathrm{~S}$ rRNA; (b) AOB; (c) AOA; (d) nriK; (e) nriS; (f) Anammox.

As previously shown [38], swine wastewater has a low biodegradable carbon source and dissolved oxygen content for anaerobic digestion following air stripping. Accordingly, the nitrogen depuration pathways may not follow the classic pathways for nitrification and denitrification. Anaerobic ammonium oxidation (Anammox) is a recently discovered nitrogen removal process, which can remove ammonium from high-concentration streams and requires less oxygen and organic carbon. In limited oxygen micro zones, $\mathrm{AOB}$ can oxidize ammonium to nitrite by consuming dissolved oxygen, thus creating an anaerobic microenvironment for the inner biofilm. The produced nitrite could then be used by anammox bacteria and converted into nitrogen gas [39]. Meanwhile, proportional nitrate can also be reduced into nitrite with sufficient COD concentrations in some micro zones that play the role of electron acceptor for the anammox reaction as well. Effluent recirculation can help establish anammox processes in this way. This might be the reason why the copy numbers of anammox were the highest in CW-3 $\left(2.08 \times 10^{7}\right)$, followed by CW-1 $\left(1.39 \times 10^{7}\right)$ and CW-2 $\left(2.31 \times 10^{6}\right)$. The study here was not designed to demonstrate how the anammox processes contribute to the total nitrogen depuration. The results indicate a significant potential for anammox in CWs treating alkaline stripped effluents, which should be explored further in future research.

\section{Conclusions}

- The feasibility of treating high-alkalinity stripped effluent in horizontal subsurface-flow CWs was assessed and deemed feasible due to the high buffering capacity and diverse functional microbial transformations of wetlands.

- Two performance enhancement strategies-effluent recirculation and intermittent artificial aeration-were investigated in three HSFCWs. A 71\% TN removal rate was achieved using both strategies simultaneously, indicating that higher oxygen concentrations improve nitrogen removal.

- Ammonia volatilization from the surface of wetlands was determined to constitute only $3 \%$ of the total ammonium removed from the high-alkalinity influent, indicating a potentially important role of biological transformations on nitrogen depuration. 
- Bacterial abundance analysis in the present study illustrated Anammox is an important process for nitrogen removal in CWs treating alkaline stripped effluent.

Acknowledgments: This work was financed by grants from the project of "The National Natural Science Funds (51308536)", "Beijing Science and Technology Council Funds (Z151100001115010)”, “National Key Technology R\&D Program (2015BAD211304)", and "Beijing Nova Program (2015B083)".

Author Contributions: This study was designed by He Keli and Wu Shubiao. Guo Luchen, Luo Hongzhen, and Dong Renjie performed the data collection and also analysis. The manuscript was prepared by He Keli and Wu Shubiao and revised by Lv Tao, Wu Shubiao, and Zeeshan Ajmal.

Conflicts of Interest: The authors declare no conflict of interest.

\section{References}

1. Lee, H.; Shoda, M. Removal of COD and color from livestock wastewater by the Fenton method. J. Hazard. Mater. 2008, 153, 1314-1319. [CrossRef] [PubMed]

2. Daverey, A.; Hung, N.T.; Dutta, K.; Ling, J.G. Ambient temperature SNAD process treating anaerobic digester liquor of swine wastewater. Bioresour. Technol. 2013, 141, 191-198. [CrossRef] [PubMed]

3. Jiang, X.; Sommer, S.G.; Christensen, K.V. Christensen, A review of the biogas industry in China. Energy Policy 2011, 39, 6073-6081. [CrossRef]

4. Holm-Nielsen, J.B.; Seadi, T.A.; Oleskowicz-Popiel, P. Oleskowicz-Popiel, The future of anaerobic digestion and biogas utilization. Bioresour. Technol. 2009, 100, 5478-5484. [CrossRef] [PubMed]

5. Kizito, S.; Wu, S.B.; Kirui, W.K.; Lei, M.; Lu, Q.M.; Bah, H.; Dong, R.J. Evaluation of slow pyrolyzed wood and rice husks biochar for adsorption of ammonium nitrogen from piggery manure anaerobic digestate slurry. Sci. Total Environ. 2015, 505, 102-112. [CrossRef] [PubMed]

6. Song, Y.H.; Qiu, G.L.; Yuan, P.; Cui, X.Y.; Peng, J.F.; Zeng, P.; Qian, F. Nutrients removal and recovery from anaerobically digested swine wastewater by struvite crystallization without chemical additions. J. Hazard. Mater. 2011, 190, 140-149. [CrossRef] [PubMed]

7. Değermenci, N.; Ata, O.N.; Yildız, E. Ammonia removal by air stripping in a semi-batch jet loop reactor. J. Ind. Eng. Chem. 2012, 18, 399-404. [CrossRef]

8. Frison, N.; Katsou, E.; Malamis, S.; Bolzonella, D.; Fatone, F. Biological nutrients removal via nitrite from the supernatant of anaerobic co-digestion using a pilot-scale sequencing batch reactor operating under transient conditions. Chem. Eng. J. 2013, 230, 595-604. [CrossRef]

9. Sica, M.; Duta, A.; Teodosiu, C.; Draghici, C. Thermodynamic and kinetic study on ammonium removal from a synthetic water solution using ion exchange resin. Clean Technol. Environ. Policy 2014, 16, 351-359. [CrossRef]

10. Rubia, M.Á.D.L.; Waller, M.; Heaven, S.; Banks, C.J.; Borja, R. Preliminary trials of in situ ammonia stripping from source segregated domestic food waste digestate using biogas: Effect of temperature and flow rate. Bioresour. Technol. 2010, 101, 9486-9492. [CrossRef] [PubMed]

11. Mayes, W.M.; Batty, P.L.; Younger, P.L.; Jarvis, A.P.; Kõiv, M.; Vohla, M.; Mander, U. Wetland treatment at extremes of pH: A review. Sci. Total Environ. 2009, 407, 3944-3957. [CrossRef] [PubMed]

12. Oon, Y.L.; Ong, S.A.; Ho, L.N.; Wong, Y.S.; Oon, Y.S.; Lehl, H.K.; Thung, W.E. Hybrid system up-flow constructed wetland integrated with microbial fuel cell for simultaneous wastewater treatment and electricity generation. Bioresour. Technol. 2015, 186, 270-275. [CrossRef] [PubMed]

13. Vrhovšek, D.V.; Kukanja, S.; Bulc, T. Constructed wetland (CW) for industrial waste water treatment. Water Res. 1996, 30, 2287-2292. [CrossRef]

14. Bulc, T.G. Long term performance of a constructed wetland for landfill leachate treatment. Ecol. Eng. 2006, 26, 365-374. [CrossRef]

15. Li, M.H.; Wen, Z.; Yu, X. Study on Removal Efficiencies of pollutant from Constructed Wetland in Aquiculture Waste Water around Poyang Lake. Procedia Environ. Sci. 2011, 10, 2444-2448.

16. Nyquist, J.; Greger, M. A field study of constructed wetlands for preventing and treating acid mine drainage. Ecol. Eng. 2009, 35, 630-642. [CrossRef]

17. Mayes, W.M.; Younger, P.L.; Aumônier, J. Buffering of alkaline steel slag leachate across a natural wetland. Environ. Sci. Technol. 2006, 40, 1237-1243. [CrossRef] [PubMed] 
18. Wang, Z.H.; Liu, X.J.; Ju, X.T.; Zhang, F.S. Field in situ determination of ammonia volatilization from soil: Venting method. Plant Natrition Fertil. Sci. 2002, 8, 205-209.

19. Throbäck, I.N.; Enwall, K.; Jarvis, A.; Hallin, S. Reassessing PCR primers targeting nirS, nirK and nosZ genes for community surveys of denitrifying bacteria with DGGE. FEMS Microbiol. Ecol. 2004, 49, 401-417. [CrossRef] [PubMed]

20. Huang, X.; Liu, C.; Wang, Z.; Gao, C.; Zhu, G.; Liu, L. The Effects of Different Substrates on Ammonium Removal in Constructed Wetlands: A Comparison of Their Physicochemical Characteristics and Ammonium-Oxidizing Prokaryotic Communities. CLEAN Soil Air Water 2013, 41, 283-290. [CrossRef]

21. Tsushima, I.; Kindaichi, T.; Okabe, S. Quantification of anaerobic ammonium-oxidizing bacteria in enrichment cultures by real-time PCR. Water Res. 2007, 41, 785-794. [CrossRef] [PubMed]

22. Huang, X.; Liu, C.; Wang, Z.; Gao, C.; Zhu, G.; Liu, L. Occurrence and distribution of veterinary antibiotics and tetracycline resistance genes in farmland soils around swine feedlots in Fujian Province, China. Environ. Sci. Pollut. Res. 2013, 20, 9066-9074. [CrossRef] [PubMed]

23. Li, B.; Irvin, S. The comparison of alkalinity and ORP as indicators for nitrification and denitrification in a sequencing batch reactor (SBR). Biochem. Eng. J. 2007, 34, 248-255. [CrossRef]

24. Sun, G.; Gray, K.R.; Biddlestone, A.J.; Allen, S.J.; Cooper, D.J. Effect of effluent recirculation on the performance of a reed bed system treating agricultural wastewater. Proc. Biochem. 2003, 39, 351-357. [CrossRef]

25. Vymazal, J. Removal of nutrients in various types of constructed wetlands. Sci. Total Environ. 2007, 380, 48-65. [CrossRef] [PubMed]

26. Rørslett, B.; Berge, D.; Johansen, S.W. Lake enrichment by submersed macrophytes: A Norwegian whole-lake experience with Elodea canadensis. Aquat. Bot. 1986, 26, 325-340. [CrossRef]

27. Schot, P.P.; Wassen, M.J. Calcium concentrations in wetland groundwater in relation to water sources and soil conditions in the recharge area. J. Hydrol. 1993, 141, 197-217. [CrossRef]

28. Mlh, B.; Wheeler, B.D. Vegetation patterns in spring-fed calcareous fens: Calcite precipitation and constraints on fertility. J. Ecol. 1989, 77, 597-609.

29. Ayaz, S.Ç.; Aktaş, Ö.; Findik, N.; Akça, L.; Kınacı, C. Effect of recirculation on nitrogen removal in a hybrid constructed wetland system. Ecol. Eng. 2012, 40,1-5. [CrossRef]

30. Lavrova, S.; Koumanova, B. Influence of recirculation in a lab-scale vertical flow constructed wetland on the treatment efficiency of landfill leachate. Bioresour. Technol. 2010, 101, 1756-1761. [CrossRef] [PubMed]

31. Abril, G.; Frankignoulle, M. Nitrogen-alkalinity interactions in the highly polluted scheldt basin (Belgium). Water Res. 2001, 35, 844-850. [CrossRef]

32. Vymazal, J. The use constructed wetlands with horizontal sub-surface flow for various types of wastewater. Ecol. Eng. 2009, 35, 1-17. [CrossRef]

33. Maltais-Landry, G.; Maranger, R.; Brisson, J.; Chazarenc, F. Nitrogen transformations and retention in planted and artificially aerated constructed wetlands. Water Res. 2009, 43, 535-545. [CrossRef] [PubMed]

34. Tanner, C.C.; Kadlec, R.H. Oxygen flux implications of observed nitrogen removal rates in subsurface-flow treatment wetlands. Water Sci. Technol. A J. Int. Assoc. Water Pollut. Res. 2003, 48, 191-198.

35. Erdirencelebi, D. Treatment of high-fat-containing dairy wastewater in a sequential UASBR system: Influence of recycle. J. Chem. Technol. Biotechnol. 2011, 86, 525-533. [CrossRef]

36. Zhi, W.; Ji, G. Quantitative response relationships between nitrogen transformation rates and nitrogen functional genes in a tidal flow constructed wetland under C/N ratio constraints. Water Res. 2014, 64, 32-41. [CrossRef] [PubMed]

37. Braker, G.; Zhou, J.; Wu, L.; Devol, A.H.; Tiedje, J.M. Nitrite reductase genes (nirK and nirS) as functional markers to investigate diversity of denitrifying bacteria in pacific northwest marine sediment communities. Appl. Environ. Microbiol. 2000, 66, 2096-2104. [CrossRef] [PubMed]

38. Tambone, F.; Genevini, P.; Imporzano, G.; Adani, F. Assessing amendment properties of digestate by studying the organic matter composition and the degree of biological stability during the anaerobic digestion of the organic fraction of MSW. Bioresour. Technol. 2009, 100, 3140-3152. [CrossRef] [PubMed]

39. Strous, M. Microbiology of anaerobic ammonium oxidation. Appl. Sci. 2000, 12, 349-360.

(C) 2016 by the authors; licensee MDPI, Basel, Switzerland. This article is an open access article distributed under the terms and conditions of the Creative Commons Attribution (CC-BY) license (http://creativecommons.org/licenses/by/4.0/). 